\title{
MARKETIZATION IN PUBLIC EMPLOYMENT SERVICES: LESSONS FROM UK EXPERIENCE FOR TURKEY
}

\section{Varol DUR}

Sosyal Güvenlik Uzmanı, Sosyal Güvenlik Kurumu, University of York, York, United Kingdom, E-posta: vd559@york.ac.uk

ORCID: 0000-0002-6801-3567

Başvuru Tarihi: 21.03.2016, Kabul Tarihi: 21.07.2017

DOI: $10.21441 /$ sguz.2017.59

\begin{abstract}
With its liberal welfare regime and different understanding on social issues, United Kingdom separates from continental European countries. These differences create opportunities for UK's governments to materialize "most advanced" neo-liberal reforms in the field of public employment services. Not only the current situation of marketized employment services in UK, but also its historical developments provide numbers of positive and negative examples for the countries planning to implement similar reforms..

This study does not reach a conclusion indicating that UK has best or worst practices in this field. However, it suggests that the UK's example contains very valuable inputs about pros and cons of marketization in public employment services and how this process should manage. In this scope, the study aims to derive lessons from UK case for Turkish public employment services from objective point of view.
\end{abstract}

Keywords: Public employment services, marketization, work programme 


\section{KAMU İSTIHDAM HIZMETLERININ PIYASALAŞMASI: BİRLEŞİK KRALLIK DENEYIMINDEN TÜRKIYE ICÇIN ÇIKARIMLAR}

\section{ÖZ}

Liberal refah rejimi ve sosyal konulardaki farklı bakış açısıyla, Birleşik Krallık, kıta Avrupası ülkerinden ayrılmaktadır. Bu farklılıklar Birleşik Krallık hükümetlerine kamu istihdam hizmetleri alanında en ileri neo-liberal reformları yapma imkanı vermiştir. Sadece kamu istihdam hizmetlerinin piyasaya açılmış mevcut durumuyla değil, aynı zamanda bu durumun tarihsel süreci benzer reformlar yapmayı planlayan ülkeleri için çok sayıda olumlu ya da olumsuz dersler sağlamaktadır.

Bu çalışma, Birleşik Krallığın bu alandaki en iyi ya da en kötü uygulamalara sahip olduğu şeklindeki bir sonuca ulaşmamaktadır. Ancak çalışma, Birleşik Krallık örneğinin kamu istihdam hizmetleri alanında gerçekleştirilecek bir piyasalaşmanın olumlu ve olumsuz yanlarıyla bu sürecin nasıl yönetilmesi gerektiğine ilişkin önemli bilgiler içerdiğini savunmaktadır. Bu kapsamda, çalışma tarafsız bir bakış açısıyla, Türk kamu istihdam hizmetleri için Birleşik Krallık örneğinden dersler çıkarmayı amaçlamıştır.

Anahtar Kelimeler: Kamu istihdam hizmetleri, piyasalaşma, çalışma programı 


\section{INTRODUCTION}

United Kingdom is a different member of European family. With its liberal tendencies in welfare and labour policies and different understanding on social issues, UK separates from continental European countries. From the viewpoint of cooperative social policy literature, UK is segregated from conservative and social democrat welfare states and located in liberal welfare state category/typology with United States. UK's relatively low level social spending, dominant market oriented approach and means tested social assistance programs with stigmatisation at certain extent are the main reasons of this clustering. These differences created opportunities for UK governments to materialize so-called "most advanced" neo-liberal reforms in the field of social policy, especially in public employment services. In that sense, UK has followed its path to implement these reforms and this path dependency made UK the champion of marketization in the field of public employment services.

Not only the current situation of marketized employment services in UK, but also its historical developments have taken a lot of attention from both academic and bureaucratic spheres. Number of countries have transferred some part of UK's reforms or have inspired from them. With its Mediterranean/Conservative welfare state like arrangements, Turkey has totally different social policy understanding than UK. However, analysing UK's experience and experiments in this field can create opportunities to reach lessons for Turkey which is the utmost aim of this paper.

Proposing to follow UK or any other county's example, purely, is meaningless in social policy field. But some policies (especially, monitoring and evaluation systems as positive side and decreasing power of voluntary non-profit organizations and social partners (third sector) as negative side) provide distinguish lessons for strengthening Turkish current public employment system and contributing future plans.

In this scope, first part of this article will give background information about individualization and marketization in public employment services. Aim of the second part is to evaluate marketization in employment services in UK and to critically analyse its negative and positive features in historical perspective started with 1997 Labour Government and reached today. By doing that, lessons will be tried to derive from wide UK experience and summarized at the end of the section. In third part, marketization process and current legislative changes in Turkish employment services will be evaluated. Some major differences between Turkey and UK will be underlined. 


\section{Individualization and Marketization in Public Employment Services}

Individualization and client-based personalize counselling services in the area of employment policies are accepted as one of the answers for complex problems of various unemployed groups by many governments. However, without introducing new kind of governance method and institutional structures, providing these services seems not possible in the context of old public employment service provisions (Zimmermann vd., 2014). Almost in every case, activation policies with a work-first focus approach in employment and social policies have been introduced with a public employment service reform and these reforms have been accepted as one of the key aspects of welfare state transformation. This process requires a restructuring because activation itself contains strong change in service providing technics. Aim of the services evolve from "people-sustaining activities that are designed to maintain the well-being of clients without attempting to change their personal attributes, toward "people-changing" or transforming services that are designed to alter the personal attributes, motivation, and behaviours of clients" (Meyers vd., 1998: 9). In this perspective, individualisation of employment services have two main aspects. Firstly, individuals are the primary focus of the supply side based interventions and they are responsible for their unemployment status. Secondly, the individual cooperation and responsibilities during transaction process are underlined (Pascal, 2007: 9).

Activation goes by with an intervention paradigm which has three key features according to Pascual (Pascal, 2007: 9). These three features could be evaluated as key philosophy of UK marketization process;

- "An individualised approach: rather than creating appropriate political conditions for the fair redistribution of wealth, the aim is to change individual behaviour, motivation and attitudes. These policies favour increased individualisation of interventions (tailored, client-centred services) and greater involvement of the beneficiary. The regulatory and legitimating benchmark for these policies is the individual.

- An emphasis on employment: the goal of these policies is employment (work focus) and autonomy. The policies are targeted at influencing individual behaviour in the labour market (providing incentives, persuading and motivating individuals). The focus is on the economic aspects of citizenship rather than on political or social ones.

- Contractualisation as a core principle, in two respects: firstly, the contract has become the fundamental metaphor as far as guiding and legitimating 
these policies is concerned, and secondly, it involves a change in the terms of the social contract that has traditionally been used to define the concept of citizenship. It has become more of a moral contract than a social or political one. Citizens' access to their rights is now conditional on their attitude and behaviour with regard to their employment."

As a result of activation policies in line with these features, a transformation from guarantor state (of social rights) to regulator state (of individual responsibilities) have been observed. In that sense, the state started to provide services for ensuring adaptation according to market needs, instead of protecting citizens against market powers (Pascal, 2007: 9).

The ongoing evolution in this field has effects on every level of public employment services. Firstly, managers and workers of the public bodies experience changes on both policy making level and daily relations with their clients. Secondly, needs of personalized service production and need of considering individual and local particularities increase. It requires flexibility and autonomy rather than following standard recipes for general population. Thus, institutions and frontline workers should have freedom to provide special solutions for specific circumstances. Thirdly, activation polies promote work first approach and provide assistances for returning to labour market based on conditions and sanctions rather than using compensatory measures for protect unemployed individuals (Van Berkel, 2008).

Reform trends generally contain decentralization, new public management, inter-agency cooperation and marketization. Marketization is one of the main common reform component from different countries. However, marketization is not a standard process. It is ranging from fully regulated system to no state intervention at all. In that sense, three key points may be used for evaluating a marketized system: Level of control over contractors and their performance, service delivery processes (state effect on what and how to be delivered) and user's freedom in the marketized market and position against contractors (Zimmermann vd., 2015). Assumptions of increasing efficiency, decreasing expenditure via providing competition and benefiting from private and third sector companies' expertise are not only justification but also driving force behind marketization process in this field in many cases. With the cooperation, marketization process leads involvement of broader set of actors such as third sector, local administrations or private companies rather than sole responsibility of public sector. On the other hand, simplifying and unifying executive departments have been served to same two purposes via decentralisation. Decentralization and new public management provide chance for lower level actors' intervention to policy making process (Larsen vd., 2014; Zimmermann vd., 2014). 
Marketization, in general, aims and causes outsourcing of the selection of suitable services from public agencies to service providers from private and voluntary sectors. When it comes to the marketization of social policies, the tendering (outsourcing) is one of the new aspects that brings the governance into this field. The scope of outsourcing can either limited to simple tasks like job placements or it can cover more complex services in close relation with the macro social policies. The tasks to be outsourced can vary from simple matching activities to more complex social services aimed at increasing the employability of an unemployed person. Quality and cost can be, individually or together, main selection criteria. The payments to the providers can make according to their performance. This performance can be determined through strict (outcome) or soft (process-related) measures. Contracts can be signed in short-term or long-term according to their aims (Van Berkel vd., 2008; Zimmermann vd., 2015). Competition is the other aspect that introduced into social policy by marketization. It indicates clear shift from public service towards market based mechanism. Competition largely takes place regulation by statue, standards and process requirements (Zimmermann vd, 2015). The main reason of this wide range of policy options is highly national character of employment and social policies. National welfare arrangements and, in more broad context, historical and current industrial relations and social-economic policies have strong effects on decision making process in such delicate fields.

\section{Development in United Kingdom's Public Employment Services}

\subsection{Labour Governments (1997 - 2010)}

According to Esping-Andersen's classic typology, the UK's welfare regime fits into the liberal welfare state category, mainly due to its three distinctive features: relatively limited state spending on social policy, common means-tested social assistance and reliance on market-oriented services (Esping-Andersen, 1990). Its liberal tendency has allowed the UK to take lead role in the scope of welfare reform in Europe. These reforms were mainly in line with the European Employment Strategy and have been followed by other member states in various ways to some extent ((Zimmermann \& Fuertes, 2014). The UK is, also, distinctive from continental Europe in terms of its constitutional and institutional policy-making mechanisms, and these differences have direct effects on its social policies. Besides some legislative and executive differences, weak trade unions and lack of social dialog mechanism have given opportunity to consecutive governments to carry on reform processes without strong oppositions and high level of interference. Thanks to its low level commitments on welfare states in compare with the other EU members, UK governments have been in good position to offer even radical reforms and they could act more straightforward. In addition to that, due to lack of corporatist relation 
in UK's government mechanism, the reforms could take place without or limited negotiation with local administration or social partners (Taylor-Gooby vd., 2004; Flemming \& Wright, 2014).

Although some experimental implementations had been put into practice towards marketization and managerialism in employment services before 1997, majority of the employment services were still provided by the public sector with limited outsourcing and support of third sector during that period ((Flemming \& Wright, 2014). However, first clear step of the process was initiated after New Labour Government came into the power in 1997 and New Deal programme was initiated in 1998 as cornerstone of new employment policies prioritized working on other social programmes (Taylor vd., 2015).

Even if new public management principles, such as competition, market incentives and performance management, became important in the governance of public services in the UK since the late 1970s, these principles had become more visible with the Labour Government between 1997 and 2010 (Taylor vd., 2015). The Labour Government underlined three features for combating poverty and increasing competitiveness after they took over the office and initiated New Deal. Firstly, the government urged to as many people as possible to into work instead of social assistance via welfare-to-work programs, making work pay through the national minimum wage and in-work tax credit. Secondly, heavily targeted state interventions including advice, training and work placements were put into practise. These interventions implemented with a degree of compulsion for some groups. Lastly, private sector was used to achieve government's targets and a policy framework for contracting out of the services was propounded by Freud Report. During their period, Labour Government aimed to consolidate centre-left policies and marketfriendly objectives. By doing this, while they tried to face with new social risks and to integrate different vulnerable groups to economic system, on the other hand, they targeted to restrain government spending and increase private sector roles (TaylorGooby vd., 2004; Zimmermann \& Fuertes, 2014).

After 1997, series of reform including the ones in the area of employment services put on the agenda for supporting to increasing British economic competitiveness and in line with the corporate governance reforms to the civil service. (Taylor-Gooby vd., 2004; Flemming \& Wright, 2014).

After 1997, for the sake of ensuring more cost-efficient and specialized employment service providing, number of services that were contracted contracting out to private and third sector providers had been increased. As pilot implementations, the services targeted some specific groups such as disabled and lone parents and some 
specific areas such as employment zones had been outsourced between late 1990s and first half of 2000. These activation programmes were supported with 'make work pay' policies for increasing the attractiveness of employment. The government implemented a minimum wage from 1999 and a series of reforms based on negative income tax for working families and child-care. This provision later extended to working people without children, disabled persons, those over 50 and pensioners. These new benefits aimed to direct people employment and were substantially higher than previous means-tested supports. Also, Jobcentre Pluses were created as onestop-shops for providing employment and some social assistance services. All these operations were realized under the concept of work first approach; everyone who become unemployed and start to get assistance should go back to work as soon as possible. Despite of this ambition and gradual increase of scope of the programmes, they were always accepted as supporter activities for public employment services during this period (Taylor-Gooby vd., 2004; Taylor vd., 2015).

Introduction of the supply chain model in mid-2000s by Department of Work and Pension (DWP) make way for consolidation of private sector contracts into larger contracts. During this period, state's role had shifted from service provider to key enabler (Flemming \& Wright, 2014) and main determinant of the period was to acceptance of private and third sector involvements as key factors of the reform process by the government. Benefiting from their involvement was accepted as a way of escaping from old fashioned one-size-fit-all approach in public employment services. Initial results of using larger contracts were evaluated as positive since some reduction in administrative burden and inefficiency were observed relative to previous years. Also, transferring risks to external organizations was taken into account of another positive output. First version of the outcome based payments and pre-black box ${ }^{1}$ style management over services were started to implement during this period. According to some scholars, the term of privatisation may more suitable than marketization for this period due to steady and rapidly increasing roles of private and third sector organization in employment services (Flemming \& Wright, 2014; Taylor vd., 2015). Affirming this view, series of DWP report from this period had declared UK's lead position about innovative supply side employment policies in the world (Lindsay vd., 2007).

Publication of Freud Report in 2007 provided very important and effective basis for further marketization process on public employment services in the UK. The report itself gained wide range of support from different political wings and draw main principles of welfare-to-work policies both last period of Labour government

1 Black Box contracts are the contracts that contractors have been given flexibility to design and deliver services and evaluated by their outputs. 
and its successor. Apart from some elements of future reforms such as new outsourcing methods, black box delivery models, personalized support and payment by results, the report's philosophy had effects on political environment. According to the report, unemployment was largely individual problem and caused from lack of employability of individuals. To overcome this problem, conditionality and sanctions should be imposed for elimination of dependency culture and behavioural causes of unemployment (Rees vd., 2014). The results of this philosophy was to prioritization of the work first approach. In that sense, quality of employment policy outcomes was neglected by the government. The supremacy of finding any job for unemployed persons (with using services such as trainings) was broadly accepted. In terms of New Deal, work-focus gateway and compulsory work-focus interviews with intensive trainings on job search technics became widespread elements of work first approach. However, delivery agencies motivated by 'quick wins' rewarded through output-oriented funding were not successful for 'finding' sustainable jobs in every cases (Lindsay vd., 2007).

\subsection{Conservative Governments (2010 - Current)}

After Conservative-Liberal Democrat Coalition Government took office in May 2010, some of the reforms that were started by the previous government have extended, amplified, and accelerated. Main motivation of the Coalition government about the reforms was austerity (Taylor vd., 2015). The initial aim of the government was to cut the annual fiscal deficit virtually to zero and to reduce national debt. But, the policies went much further than this aim and turned into major re-organization of all public sector including social services. Ultimate goal was determined as eliminating future pressures that may cause due to welfare spending via further structural changes. In this scope, its social reform program "is of interest because it represents the most far-reaching and precipitate attempt to achieve fundamental restructuring in an established welfare state in a larger Western economy in recent years" (Taylor-Gooby, 2012: 61). Therefore, the coalition's actions towards marketization in employment services have become more rigid than its predecessor and these efforts have materialized as main employment service reform, namely the Work Programme.

\subsubsection{Key Alterations from the Previous Period}

The Work Programme contained high level of alteration about distribution of the roles and sources compering with the previous employment programmes and marketization process. Firstly, the programme contained relatively larger prime contracts. While holders of these prime contracts have right to give all the services themselves, they can, also, use subcontractors for some or all end-to-end supports to their clients (tier one) or they can benefit from specialist providers for groups who 
need special services (tier two). Main transformation here is that DWP has no any contractual relation with small (tier one and two) providers, anymore. It only deals with prime contractors. Being a prime contractor is required substantial financial capacity due to wide geographical and service coverage of one contract. The moderate level providers who have not enough power for acquiring prime contract, has felt great pressure to remain in the game, even if they had experience with large contracts in previous system. On the other hand, due to increasing contract size and extending financial opportunities, new entrances to the UK employment market have been realized from proximate fields or abroad. These 'intruders' with their wider financial sources and experience in similar fields have become strong competitor for local providers. This competition sometimes can cause downgrades of previous system's prime contractors and push them towards lower tiers of supply chain (Taylor vd., 2015). In addition to all of these factors, extended nature of narrow range of private contractors leads to downgrade of the voluntary sector agencies and local authorities' role as a subcontractors in the system (Flemming \& Wright, 2014).

Secondly, importance of payment by results as financing model has dramatically increased with the Work Programme relative to former programmes. Compared to provider in New Deal Programme, prime contractors of the Work Programme are paid considerably low level of initial attachment fee for each client allocated by DWP. Most of the payments can be only claimed after ensuring sustainable employment. While within the ratio between initial attachments, job replacement and sustain job outcome was nearly 40:30:30 in Flexible New Deal, same ratio is approximately 10:25:65 in the Work Programme. This comparison shows relative importance of performance outcomes in the Programme (Rees vd., 2014). Also, amongst other European countries, performance base payment system is implemented the most strictly in UK (Van Berkel vd., 2012).

Thirdly, unlike various group-specific New Deals, the Work Programme's coverage is much wider and it has been designed to provide services to all different kind of unemployed groups in single employment scheme. This unification of service provision was constituted in parallel with unification of benefit system. Due to increase of groups who need specific attention and various specialized services, more autonomy is granted to prime contractors. Opposite from New Deal which contained mandatory service components, the Work Programme operates under black box delivery model which gives almost total autonomy to prime providers. Even, minimum service requirements are set by each prime providers for themselves. Adaptation of black box model is accepted as the reason and necessity of meeting the needs of more personalisation, in other word individualisation, in employment services. This adaptation indicates a shift from providing predefined services to 
flexible and least standardise model (Borghi \& Van Berkel, 2007; Rees vd., 2014). The new design has given chance to produce "tailored services around the individual's circumstances than ever before”. (Merran vd., 2012: 309).

\subsubsection{The Challenges and Drawbacks of the Work Programme}

Very first challenge of the Work Program is to merge very different unemployed groups into one umbrella programme.. DWP main solution against this hardship is to give great autonomy to the prime contractors. In this autonomy, providers have to find a way of job placement for their clients coming from nine different unemployed groups. The success level of providers for each unemployed (client) group are, individually, important, since the purchaser make its payments according to average difficulty of transition to employment of these client groups. As it explains with the term of differentiated universalism, taken from Lister's terminology, DWP aims to encourage providers for service equality to all groups while taking differences into consideration. As a result, DWP targets to prevent different approaches to different client groups (namely, creaming and parking ${ }^{2}$ ) according to their distance to transition to labour market. DWP claims that the system designed in way not to allow contractors be able to profit, unless they provide necessary services to high number of disadvantage groups. However, concerns about creaming and parking were mention in not only academic papers but also official documents, despite differentiated payment regime (PAC, 2013). According to Rees and others, disabled people and young lone parents experience relatively lower job outcome rates than job ready groups for both in and between groups. They claims that "at present, it seems the Work Programme design may not have struck the right balance between value for money, incentives and claimant protections." (Rees vd., 2014: 236; Rees vd. 2013).

Creation of a programme such as the Work Programme for dealing with mainly long-term employment problems of various groups, coming from different background and having different needs, require combination of multiple social services which enable individual service provision. Individualization of employment services in UK indicates a shift for state from providing welfare provision to combating against welfare dependency. This shift could have been observed since establishment of work first approach in UK. With work-focused interviews and

2 Creaming: Providers focused on clients who are closest to the labour market and targeting services on them in the expectation that they are more likely to trigger an outcome payment.

Parking: Individuals deemed to be unlikely to generate an outcome payment are de-prioritized, perhaps receiving the minimum service specified in the contract.

Creaming and parking can be observed more likely in the systems such as regulatory controls or organizational norms or incentives against them are low and, naturally, in the providers solely interested in short term profit anticipations. 
different activity options, New Deal was one of the first implementation to introduce high level of individualisation elements in the world as discussed above. However, in opposite to this initial purpose, a standardization between the private providers with the aim of streamlining their services for gaining competitive power has started to occur as a result of increasing level of marketization after the Work Programme (Pascual, 2007; Heidenreich \& Aurich-Beerheide, 2014). On the other hand, the work programme contains punitive measures for pushing clients to taking responsibility. This kind of active involvement policy aims to create behavioural changes in society towards certain and standardized way under strong supervision (Pascual, 2007). These policies can form great stress on unemployed individuals and "create the conditions for moving welfare from an income redistribution scheme to a behaviour modification regime" (Schram, 2000: 82). On the one hand, The Work Programme gives great responsibility to clients in both philosophical and practical level, on the other hand, proper client compliment mechanism has not been established. Clients have no chance to choose or change their providers. In that sense, administrative and democratic accountability have been declined and the system bases on performance accountability which consists of DWP' evaluation on the contracters (Jantz vd., 2015).

On the other hand, multilevel and various types of actors' involvement are very crucial in for successful implementation of activation policies. Firstly, local and specialized institutions involvement are needed to answer specific needs of disadvantages groups. Local administrations and related stakeholders should be empowered by decentralisation in the scope of activations policies. Multistakeholder approach containing public, private and third sector cooperation, also, helps cost reduction and designing of targeted policies. Secondly, a multilevel approach towards activation is needed. Despite international trends, due to the work programme design, UK is accepted highly centralised country in the area of employment policy. Income maintenance transfers are controlled centrally and purchaser role is played by DWP. Local administrations have no managerial role in centralized employment service system. Also, Jobcentre Plus's executive agency role on local basis was removed in 2011. Therefore, low of multilevel integration can be observed (Heidenreich \& Aurich-Beerheide, 2014). In addition to that, as mention above, due to contracting out mechanism, small companies and third sector organizations have been hierarchically pushed down and this situation has harmed multi-actor involvement. Opposite of continental European countries such as France where voluntary organization is deliberately protected against market power, UK can be accepted only country example that follow this path. Only coordination in this field, which had been accomplished, seems integration of central level agencies and programmes (Van Berkel vd., 2012; Zimmermann vd, 2015). 
Type of employment services that contracting out is another challenge of the Work Programme. UK is the only country where employment services for long term employment (relatively hard to employ) have been marketized. In opposite to UK's case, general tendency in different countries such as Germany, the Czech Republic, France, Sweden, Switzerland and the Netherlands is to contract out employment services for more ready-to-employ groups. Also, the Work Programme is one of the rear implementation with very strict split between purchasers and providers. Apart from UK, The Netherlands and Switzerland, the purchasers also act as providers in most countries. These two facts increase importance of quality of activation policies for clients. Due to drawbacks mention previous paragraph, distance of groups to employability and very limited public intervention to relation between providers and clients are the major sources of doubts on the Work Programme's efficiency and equality (Van Berkel vd., 2012).

In addition to reasons mention above, third sector contribution to the programme should be assumed very important, since DWP introduced the Work Programme as one of the ways of enhancing civil society's role in delivering social services and a very important contribution to the big society. However, when looking the figures, it seems that third sector participation has remained low. $11 \%$ of primes, $41,2 \%$ of tier I provider and $51,1 \%$ of tier 2 providers are from third sector in 2013. According to Rees and others, third sector providers have been squeezed out of the welfare to work market due to the back ended payment model, limited financial sources and fierce competition caused by the work programme's structure, itself. Especially for the specialist providers focusing on only one specific group (such as former convicts) can get only tier two roles, even if tier one contracts are much more safe (sustainable and profitable) positions. Due to their limited financial rewards and bargaining power, several these kind of providers either try to evolve into institutions which produce more generic services for wider groups (for gaining ability to provide end-to-end services) or face to risk of washing out, eventually. Also, the programme's performance mechanism seems to design for normal economic conditions and average client. This design creates problems in time of crisis and for disadvantages groups. (Rees vd., 2013; Taylor vd., 2015).

As summery of discussion above, these negative and positive particularities of UK experience can be underlined.

- Fair, simple but strict performance-based evaluation and monitoring can not only boosts efficiency and competition, but also help to prevent creaming problem. However, shifting from rule-based procedural governance to black box style management, on the one hand, provides freedom for private companies' operation, but on the other hand, increases necessity of advanced monitoring mechanisms for public authorities. 
- Providing costly and specific services to the small number of clients with special needs can be main problem of marketized employment services. Lack of specialized institutions working with specific groups would likely increase parking problem for disadvantage individuals. Third sector involvement would be very good balance mechanism between profit aimed streamline private companies and public interests,

- Network governance and relations with stakeholders are crucial for both preparing and implementing reform processes that potentially effected everybody in the society,

- Instead of direct marketization of disadvantages groups' services, starting with ready-to-employed groups could be more suitable, especially when taking into consideration problems in third sector participation.

- As it in UK case, dealing with only limited number of prime contracts would be easier for a public authority instead of limitless small companies. However, a system should be established for protecting competition and preventing merging. In this scope, UK's tender process in this field can be accepted as a good example.

\section{Marketization in Turkish Public Employment Service}

Marketization process in Turkish public employment services has been introduced as a necessity for modernization of service delivery mechanism, increasing quality and keeping up with global trends. It was explicitly underlined that due to complexification of global and local economic conditions, private actors' involvement to the field of employment services became crucial. On the other hand, it was stated that adaptation of EU and ILO legislations ${ }^{3}$ required to restructuring on public employment service field. In the scope, first attempt was establishment of Private Employment Agencies (PEA) in 2002. It was clearly indicate in the related law's preamble, this agencies' roles were limited to assist the public employment agency (ISKUR) with only job placement (General National Assembly of Turkey, 2002). Mainly due to very strong opposition coming from trade unions and interventions of other politic figures, in addition to majority of job placement, all other employment services including trainings have been continued to provide by ISKUR (Güler, 2015).

A major expansion of PEA's roles has been took place in 2016. In accordance with new legislation, the right to establish temporary employment relation have been granted to PEA. The government underlined same reasons with first wave of the

3 EU Directive no: 2008/104/EC and ILO Convention no: 181 
marketization to justify this expansion. Thanks to this new legislation, in addition to former job placement, PEAs can hire employer and "rent" them to different employees. However even after this change, the roles of PEAs still very limited in Turkey. The system does not foresee any kind of payment from ISKUR to PEAs. The companies' payments made by employers. Whole system is heavily regulated and it bases on procedural checks and monitoring made by public sektor. Also, the central government have right to nullify contracts of PEAs by the reason of violation of employers' rights. Instead of a limited tender process, the contract can granted any applicant who satisfy the conditions. However, competition is anticipated between companies once they enter the market (Prime Ministry of Turkey, 2016).

Even if above mentions features could be evaluated as programme related differences between Turkish and UK's processes, there is, also, a philosophical difference, which is the reflection of path dependency in the area of social policy, between Turkey and UK. As it underlined before, employment service reform has been conducted very straightforward in UK mainly due its liberal roots. Due to its conservative, state/bureaucracy based (even patriarchal) welfare state understanding and corporatist relations, Turkey could not materialized such bold reforms even if justifications of the processes in two countries were alike. Apart from that, according to some comments, when taken high level of informality, high number of unqualified jobs and low awareness on social rights into consideration, even low level of marketization in Turkish employment services may create more problems than solutions (Erkan Aydoganoglu, 2016).

\section{CONCLUSION}

According to Considine (taken from Zimmermana and others, 2015) marketization could be useful device for cost reduction and replacing old programmes with its strong emphasis on efficiency, however it does not automatically guarantee quality service delivery in new and complex structures. As it seen in the UK case, marketization in employment services has brought its own advantages and disadvantages. Increasing in efficiency and opportunities on cost containment have been followed by results not always coherent with public interest and values. This mismatch is much clearer when it comes to conflict between long-term interests of public and short term interest of private providers (Zimmermann vd, 2015). However, all the efforts made by subsequent governments has been in line with liberal traditions of UK.

UK case is providing a laboratory for countries who wants to implement such reforms. As it seen in the Turkish official documents, similar reasons with UK can be used as justifications of attempts for marketization in employment services 
such as cost reduction, increasing efficiency or competitiveness. Even if only moderate reforms have been materialized in this field due to Turkish welfare state's background, relatively UK, an intention can be observed for further restructuring. In this scope, these lessons can be derived from UK experiences;

First is about monitoring and evaluation of PEAs. ISKUR is tasked with monitor to PEAs via quarterly reports of activities in current situation. These reports mainly are evaluated for understanding of compliance level of PEAs to legislation and ensuring temporary employers' rights. While the monitoring mechanism does not foresee any incentives, violations of the rules are punished in a wide range of penalties from fines to contract cancelation. There are no elements for measuring performances of the agencies. Even if the current system does not envisage direct payments made by ISKUR, it counts on PEAs' performance as complementary actors in the field. Therefore, increasing managerialization via target based monitoring could be boost efficiency and competition. Introduction of these kind of governance in this field will also help to cover the justification mentioned in the law's preamble which underlines the importance of private sector participation due to changing environment in economy and labour market.

Secondly, despite limited involvement of private actors, it is impossible to talk about multi-actor or multilevel approach in Turkish employment services. Third sector involvement has not been regulated. However, as it seen above, third sector involvement is crucial for activation and individualization of the services. The lack of third sector contribution and risks derived from this situation are widely criticized in the literature (Rees vd., 2013; Flemming \& Wright, 2014; Taylor vd., 2015). Clear absence of network governance in Turkish employment services is not only indicates lack of personalised services production capacity, but also it reflect policy making process negatively as it seen in the example of more than 10 years delay in extension of PEAs roles. 


\section{REFERENCES}

Aydoganoglu, Erkan., (2016, 9 Mart). Özel İstihdam Büroları ve Kiralik Işçilik: Amaç Işçilerin Tüm Yaşamini Denetim Altina Almak [Private Employment Agencies and Renting Workers: The Aim is to Control All Life of Workers], Evrensel Newspaper.

Berkel , Rik Van., \& Vando, Borghi (2008), Introduction: The Governance of Activation Social Policy and Society, 7(3).

Berkel, Rik Van., Sager, Fritz., \& Ehrler, Franziska (2012). The Diversity of Activation Markets in Europe, International Journal of Sociology and Social Policy, $32(5 / 6)$.

Colin, Lindsay., Mcquaid Ronald W., \& Dutton Matthew (2007). New Approaches to Employability in the UK: Combining 'Human Capital Development' and 'Work First' Strategies?, Journal of Social Policy, 36.

Esping-Andersen, Gøsta, 1990. Three Worlds of Welfare Capitalism, Princeton, NJ: Princeton University Press.

Flemming, Larsen., \& Wright Sharon (2014). Interpreting the Marketization of Employment Services in Great Britain and Denmark, Journal of European Social Policy, $1-15$.

Flemming, Larsen., \& Wright Sharon (2014). Interpreting the Marketization of Employment Services in Great Britain and Denmark, Journal of European Social Policy, $1-15$.

General National Assembly of Turkey (2002). Türkiye İş Kurumu Kanunu Gerekçesi ve Komisyon Tutanakları [Turkish Employment Agency Act's Preamble and Related Commission Minutes].

Guler, Mehmet Atilla., (2015). Ulusal İstihdam Stratejisi Bağlamında Türkiye'de Güvencesiz Çalışma [Unsecure Working in Turkey in the Scope of National Employment Strategy], Çalışma ve Toplum Dergisi, 2015/3.

Heidenreich, Martin., \& Aurich-Beerheide, Patrizia., (2014). European Worlds of Inclusive Activation: The Organisational Challenges of Coordinated Service Provision, International Journal of Social Welfare, 23.

Meyers, M., Glaser, B. \& Mac Donald, K. (1998). On the Front Lines of Welfare Delivery: Are Workers Implementing Policy Reforms?, Journal of Policy Analysis and Management, 17(1). 
Pascual A. Serrano (2016, Mart 4). Reshaping Welfare States: Activation Regimes in Europe, http://www.peterlang.com/PDF/Buecher/Intro/21048_Intro.pdf adresinden ulaşılmıştır.

Public Accounts Committee (PAC) (2013). Department for Work and Pensions: Work Programme Outcome Statistics, Thirty-third report of session 2012-13, London: The Stationery Office.

Prime Ministry of Turkey (2016, Mart 15), Justification of Amendments on Labour Law and Turkish Employment Agency Act, http://www2.tbmm.gov.tr/d26/1/1-0597. pdf adresinden ulaşılmıştır.

Rees, James,. Taylor, Rebecca,. \& Damm, Chris (2013). Does Sector Matter? Understanding the Experiences of Providers in the Work Programme, Third Sector Research Centre, Working Paper, 92.

Rees, James,. Whitworthb, Adam,. \& Carterb, Elle (2014). Support for All in the UK Work Programme? Differential Payments, Same Old Problem, Social Policy \& Administration, 48 (2).

Schram, Sanford F. (2000), In the Clinic: The Medicalization of Welfare, Social Text, 18 (1) 62.

Jantz, Bastian., Klenk Tanja., Larsen, Flemming., \& Wiggan Jay (2015). Marketization and Varieties of Accountability Relationships in Employment Services: Comparing Denmark, Germany, and Great Britain, Administration \& Society, 1-25.

Taylor-Gooby, Peter., Larsen, Trine., \& Kananen, Johannes (2004), Market Means and Welfare Ends: The UK Welfare State Experiment, Journal of Social Policy, 33 (4).

Taylor-Gooby, Peter (2012). Root and Branch Restructuring to Achieve Major Cuts: The Social Policy Programme of the 2010 UK Coalition Government, Social Policy \& Administration, 46 (1).

Taylor, Rebecca., Rees, James., \& Damm, Christopher (2015). UK Employment Services: Understanding Provider Strategies in a Dynamic Strategic Action Field, Policy and Politics, 10.1332/030557314X14079275800414.

Toerien, Merran., Sainsbury, Roy., Drew, Paul., \& Irvine, Annie., (2012). Putting Personalisation into Practice: Work Focused Interviews in Jobcentre Plus, Journal of Social Policy, 42 (2),309 - 327. 
Vando, Borghi,. \& van Berkel Rik (2007). Individualised Service Provision in an Era of Activation and New Governance, International Journal of Sociology and Social Policy, 27 (9/10).

Zimmermann, Katharina., Aurichb, Patrizia., Grazianoc, Paolo R., \& Fuertes, Vanesa (2014). Local Worlds of Marketization - Employment Policies in Germany, Italy and the UK Compared, Social Policy \& Administration,48(2).

Zimmermann, Katharina., Aurich, Patrizia., Graziano, Paolo R., \& Fuertes, Vanesa (2016, Mart 20). Marketization and Activation Policies Germany, Italy and the United Kingdom Compared. http://researchrepository.napier.ac.uk/7469/ adresinden ulaşılmıştır.

Zimmermann, Katharina., \& Fuertes, Venesa (2014). Employment Policy Implementation Mechanisms in the European Union, The United Kingdom and Germany, Employment Policy Department, Employment Working Paper, No. 160. 